\title{
Reduction of thyroxine uptake into cerebrospinal fluid and rat brain by hexachlorobenzene and pentachlorophenol
}

\author{
J.A.G.M. van Raaij ${ }^{\mathrm{a}, \mathrm{b}}$, C.M.G. Frijters ${ }^{\mathrm{b}}$, L. Wong Yen Kong ${ }^{\mathrm{b}}$, \\ K.J. van den Berg*b.c ${ }^{\text {, W.R.F. Notten }}{ }^{\text {a.b }}$ \\ anstitute of Public Health and Social Medicine, Erasmus University Rotterdam. \\ Rotterdam. The Netherlands \\ ${ }^{\mathrm{b}}$ TNO Medical Biological Laboratory, Rijswijk, The Netherlands \\ ${ }^{c}$ TNO Nutrition and Food Research Institute, Division of Toxicology, Department of Neurotoxicology, \\ P.O. Box 5815, $2280 \mathrm{HV}$ Rijswijk, The Netherlands
}

Received 18 January 1994; accepted 18 April 1994

\begin{abstract}
In the present study the effects of hexachlorobenzene (HCB) and the metabolite pentachlorophenol (PCP) were investigated with respect to uptake of thyroxine (T4) into cerebrospinal fluid (CSF) and brain structures of rats. [ $\left.{ }^{125} \mathrm{I}\right] \mathrm{T} 4$ was taken up into CSF of control rats by a relatively slow process, reaching a steady state after about $3 \mathrm{~h}$. Both repeated dosing of HCB and single doses of PCP caused decreased uptake of $\left[{ }^{125}\right.$ I]T4 into CSF, total brain tissue as well as specific brain structures, such as occipital cortex, thalamus, and hippocampus. Although HCB-treatment caused a build-up of HCB and PCP levels in serum in brain only $\mathrm{HCB}$ was present in significant amounts ( $16 \%$ of the serum level). In CSF, both HCB and PCP concentrations were below detection levels. Separate experiments with PCP showed, however, a dose- and time-dependent uptake of PCP into CSF. The present results indicate that PCP and the parent compound HCB are able to affect brain supply of T4. This may have consequences for an adequate development of the brain or proper brain function in adults. The exact mechanisms of interference of PCP and/or HCB in brain uptake of T4 remain to be established.
\end{abstract}

Keywords: Hexachlorobenzene (HCB); Pentachlorophenol (PCP); Cerebrospinal fluid (CSF); Transthyretin (TTR); Thyroxine (T4); T4-transport; Brain

* Corresponding author. 


\section{Introduction}

From several studies it has become clear that hexachlorobenzene (HCB), which is produced as a by-product in industrial processes and formerly used as a fungicide, may cause disturbances of thyroid homeostasis of several species including humans (Peters et al., 1982; Rozman et al., 1986; Van Raaij et al., 1991a, 1993a,b; Den Besten et al., 1991). Other chlorinated aromatics such as polychlorinated biphenyls (PCBs), polybrominated biphenyls and dioxins induce similar effects (Collins et al., 1977; Brouwer and Van den Berg, 1986; Byrne et al., 1987; Van den Berg et al., 1988; Brouwer, 1991; Curran and DeGroot, 1991). In fact, reductions of serum thyroid hormone levels are among the most sensitive indicators of exposure to these compounds in experimental studies (Van den Berg et al., 1988; Den Besten et al., 1991; Gray et al., 1993).

A major mechanism responsible for decreases of thyroxine (T4) in the circulation after exposure to HCB or PCBs appears to be increased metabolism of T4 through an increased biliary clearance (Bastomsky, 1974; Bastomsky et al., 1976; Kleinman de Pisarev et al., 1989, 1990; Davies and Franklyn, 1991; Barter and Claassen, 1992; Van Raaij et al., 1993a) and induction of several types of T4 UDP-glucuronyltransferases (Beetstra et al., 1991; Van Raaij et al., 1993a; Visser et al., 1993a,b). Interference of pentachlorophenol (PCP), the major oxidative metabolite of HCB (Koss et al., 1976; Ahlborg and Thunberg, 1980; Van Ommen et al., 1985, 1986) with T4 binding sites of $\mathrm{T} 4$ binding serum proteins has also been found to play a role (Van den Berg, 1990; Van Raaij et al., 1991b; Den Besten, 1991, 1992). In vitro studies demonstrated that this interaction was of a competitive nature, and that the highest affinity was observed with transthyretin (TTR) (Van den Berg, 1990; Van den Berg et al., 1991), a major transport protein for T4 in rats. Additional evidence for a competitive mechanism was also obtained from in vivo and ex vivo studies (Van Raaij et al., 1991a,b, 1993b). Recent evidence suggests that after repeated exposure of rats to HCB both types of mechanisms, i.e., enhanced metabolism by HCB and competitive interactions by the metabolite PCP, may operate independently and to an equal degree in reducing serum T4 levels (Van Raaij et al., 1993b).

As a consequence of decreased peripheral thyroid hormone levels, target organs and tissues may be insufficiently supplied with thyroid hormone. Of special interest is the brain because it has been suggested that TTR might play a role for the transport of T4 through the blood-cerebrospinal fluid (CSF)-barrier (Dickson et al., 1987; Schreiber et al., 1990; Nilsson et al., 1992). The choroid plexus forms part of the blood-CSF barrier and a considerable amount of data indicate that TTR is newly synthesized by the epithelial cells of rat and human CP independently from hepatic production of TTR (Aleshire et al, 1983; Dickson et al., 1985a,b, 1986; Dickson and Schreiber, 1986; Herbert et al., 1986; Kato et al., 1986; Soprano et al., 1986). In addition, evidence for a saturable transport system for T3 in the blood-CSF barrier (Preston and Segal, 1992) has been described. HCB and/or PCP could alter brain supply of thyroid hormones through various routes, e.g., via decreased blood levels or via interference in transport systems. Alternatively, transport into the CSF and the brain of xenobiotic compounds that have a high affinity for TTR, e.g., PCP, might be facilitated. 
Thus far, little information is available concerning effects of these and other compounds with respect to the brain supply of thyroid hormones or their specific uptake into the brain. This could be relevant for the interpretation of neurotoxicity and developmental toxicity associated with halogenated aromatic compounds (Rogan et al., 1986; Tilson et al., 1990; Goldey and Taylor, 1992; Rogan and Gladen, 1992).

The purpose of the present study was to investigate in an experimental rat model whether exposure to HCB or PCP would influence T4 uptake into CSF and brain structures. This was correlated with measurements of HCB and PCP in brain and CSF. Finally, entry of PCP into CSF was determined separately.

\section{Materials and methods}

\subsection{Chemicals}

$\left.{ }^{125} \mathrm{I}\right] \mathrm{T} 4(\mathrm{SA} 1500 \mu \mathrm{Ci} / \mu \mathrm{g}=55.5 \mathrm{MBq} / \mu \mathrm{g})$, was obtained from Amersham (England), HCB and PCP from Aldrich Company (Brussels, Belgium).

\subsection{Animals, housing and treatment}

In all experiments, male WAG-RIJ rats of about 14-15 weeks old, weighing 200-250 g were used. They were housed in groups of three to four on a 12-h lightdark cycle with free access to food and water. For experiments with HCB, groups of rats $(n=3-5)$ were repeatedly treated (three times a week) with an emulsion of HCB $(40 \mathrm{mg} / \mathrm{ml}, 0.5 \%$ Tween-20 in water), or vehicle (control animals) by gavage for two (exp 1) or 4 weeks (exp 2), using different doses (0-3.5 mmol HCB/ $\mathrm{kg}$ ). Body weight and temperature were recorded three times per week. No signs of systemic toxicity were observed. Following the last dose (day 14 and day 46 of exp 1 and exp 2 , respectively), brain uptake of T4 was determined. In experiments with PCP, different doses $(0-0.105 \mathrm{mmol} / \mathrm{kg})$, as a solution in corn oil $(1 \mathrm{ml})$ were administered i.p. to groups of rats $(n=3-4)$. Control animals received corn oil only.

\subsection{Uptake of T4 into CSF}

$\left[{ }^{125}\right.$ I]T4 from a stock solution in $70 \%$ ethanol and $30 \%$ water was gently concentrated by a nitrogen flow to remove ethanol. The remainder was taken into PBS ( 8 $\mathrm{mM} \mathrm{Na} 2 \mathrm{HPO}_{4} \cdot 2 \mathrm{H}_{2} \mathrm{O}, 1.5 \mathrm{mM} \mathrm{KH} \mathrm{PO}_{4}, 140 \mathrm{mM} \mathrm{NaCl}, 2.5 \mathrm{mM} \mathrm{KCl}$ ). In order to characterize the uptake of $\mathrm{T} 4$ in the $\mathrm{CSF}$, rats were brought under ether anaesthesia, and the jugular vein was prepared for injection of $5-10 \mu \mathrm{Ci}(185-370 \mathrm{kBq})\left[{ }^{125} \mathrm{I}\right] \mathrm{T} 4$ $(200-300 \mu \mathrm{l})$. The open wound was closed with special woundclips. For collection of CSF, puncture of the cisterna magna was done at several times $(0.5-24 \mathrm{~h})$ after injection. Only CSF samples not contaminated with blood were further analysed. In all experiments, radioactivity in CSF was determined by gamma counting.

\subsection{Uptake of $T 4$ in brain}

Uptake of T4 in brain structures was determined by i.p. injection of animals with $\left.25 \mu \mathrm{Ci}(925 \mathrm{kBq}){ }^{125} \mathrm{I}\right] \mathrm{T} 4 \mathrm{in} 1 \mathrm{ml}$ of saline. Approximately $1 \mathrm{~h}(\exp 1)$ or $6 \mathrm{~h}(\exp$ 2) later, the animals were killed by decapitation for isolation of brains. Brains were dissected (or not) in several brain structures, e.g., occipital cortex (OC), hippocampus (HP) and thalamus (TH). Structures were weighed and radioactivity was determined in a gamma counter. 


\subsection{Tissue levels of $H C B$ and $P C P$}

HCB and PCP concentrations in CSF and sera from exposed animals were analysed by HPLC as described earlier (Van Raaij et al., 1991a). For determination of brain levels of HCB and PCP, brains were isolated and homogenized in a 4-fold volume of cold saline. HPLC analysis was carried out as described before (Van Raaij et al., 1991a) except that HCB was extracted with ethylacetate $(5 \mathrm{ml})$, and PCP with $n$-hexane $(4 \mathrm{ml})$ under acid conditions. The detection limit for analysis of PCP in sera or CSF was $0.14 \mu \mathrm{mol} / 1$ and for HCB $0.35 \mu \mathrm{mol} / 1$, with recoveries of $100 \%$. The detection limit for analysis of PCP in brain homogenates was $0.05 \mathrm{nmol} / \mathrm{g}$ wet tissue weight, and for $\mathrm{HCB} 0.16 \mathrm{nmol} / \mathrm{g}$, with recoveries of 97 and $92 \%$, respectively.

\subsection{Statistical evaluation}

In order to determine differences between control and experimental animals, statistical evaluation was done with Student's $t$-test.

\section{Results}

Uptake of radiolabelled T4 into CSF was first examined in non-treated control animals. The kinetics revealed a gradual increase of radioactivity into CSF during the first hours after injection (Fig. 1). The highest levels in CSF were found between 3 and $7 \mathrm{~h}$ and thereafter slowly declined. When $\left[{ }^{125} \mathrm{I}\right] \mathrm{T} 4 \mathrm{was}$ administered to rats after repeated treatment with two different doses of HCB for 2 weeks, significantly decreased amounts of label in CSF were observed ( 30 and $37 \%$ decrease, respectively, $P<0.05)$ compared to control values but no clear dose-response relationship was found (Table 1).

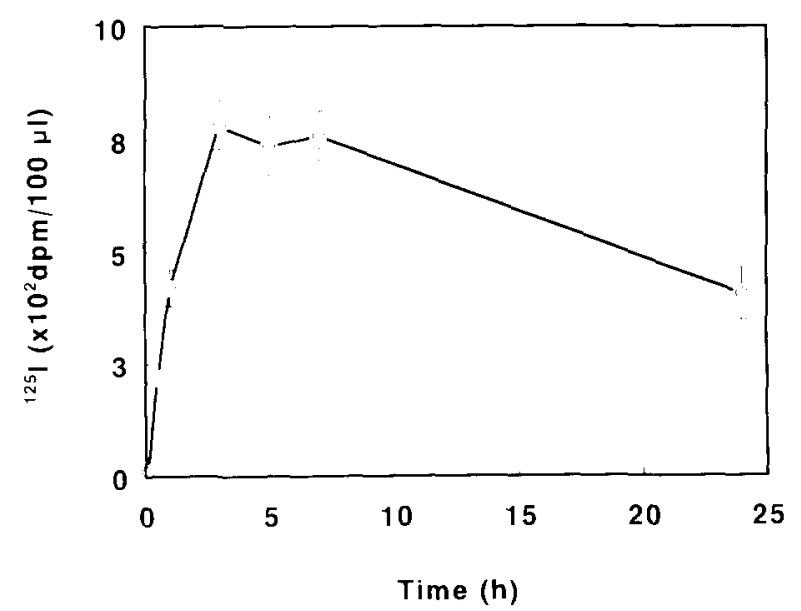

Fig. 1. Uptake of T4 into CSF. $\left[{ }^{125} 1\right] \mathrm{T} 4$ was administered i.v. to rats $(n=3-4)$. At several times after injection, CSF was sampled and radioactivity in a volume of $100 \mu \mathrm{l}$ was determined. Results are expressed as mean \pm S.E.M. 
Table 1

Effect on uptake of T4 into CSF in rats dosed with HCB

\begin{tabular}{lll}
\hline Dose $(\mathrm{mmol} / \mathrm{kg})^{\mathrm{a}}$ & CSF $(\mathrm{dpm} / 100 \mu \mathrm{l})$ & Percent change \\
\hline 0 & $826.9 \pm 98.0$ & \\
2.6 & $524.2 \pm 74.2^{*}$ & -37 \\
3.5 & $582.5 \pm 124.2^{*}$ & -30
\end{tabular}

Groups of rats $(n=3-5)$ were repeatedly dosed with HCB or vehicle as indicated for a period of 2 weeks. Following the last dose (day 14), [ $\left.{ }^{125} \mathrm{I}\right] \mathrm{T} 4$ was injected i.v., CSF was collected after $1 \mathrm{~h}$ and animals were exsanguinated. Radiolabel in CSF was determined by gamma counting. Results are expressed as mean values \pm S.D. Statistical significance: ${ }^{*} P<0.05$.

${ }^{a}$ Dose in $\mathrm{mg} / \mathrm{kg}: 750$ and 1000 , respectively.

Treatment of rats with PCP, as a single dose, did result in a dose-dependent decrease of uptake of $\left[{ }^{125} I\right] T 4$ into CSF (34-75\% decrease, Table 2).

The effect of HCB-treatment on the uptake of $\left[{ }^{125} \mathrm{I}\right] \mathrm{T} 4$ in whole brain tissue and selected brain structures is shown in Table 3 . In whole brain tissue, significant reductions (by $\pm 46-55 \%, P<0.05$ ) in the content of label were observed. In addition, strongly reduced levels of label (by $\pm 42-56 \%, P<0.05$ ) were found in each of the specific structures examined, e.g., occipital cortex, hippocampus and thalamus (Table 3). No specific differences in the magnitude of the reductions were found between the various brain structures on the one hand, and between brain structures and total brain tissue on the other.

The effect of treatment with $\mathrm{HCB}$ on the accumulation of $\mathrm{HCB}$ and $\mathrm{PCP}$ in rat brain, CSF and in serum is shown in Table 4. After a period of 4 weeks, a substantial concentration of HCB could be measured in brain tissue. The concentration of PCP in brain, however, was below the detection limit. In CSF, neither HCB nor PCP were found in concentrations above the detection limit. In serum there was a time-

Table 2

Effect on uptake of T4 into CSF in rats dosed with PCP

\begin{tabular}{lll}
\hline Dose $(\mathrm{mmol} / \mathrm{kg})^{\mathrm{a}}$ & CSF $(\mathrm{dpm} / 100 \mu \mathrm{l})$ & Percent change \\
\hline 0 & $670.8 \pm 105.5$ & \\
0.026 & $441.7 \pm 29.1^{*}$ & -34 \\
0.052 & $266.2 \pm 52.6^{*}$ & -60 \\
0.105 & $165.2 \pm 18.1^{*}$ & -75
\end{tabular}

Groups of rats $(n=3-4)$ received a single injection of different doses of PCP i.p. After a period of $4 \mathrm{~h}$ following dosing, [ $\left.{ }^{125} \mathrm{I}\right] \mathrm{T} 4 \mathrm{was}$ injected iv., CSF was collected after another $2 \mathrm{~h}$ and animals were exsanguinated. Radiolabel in CSF was determined by gamma counting. Results are expressed as mean values \pm S.D.

Statistical significance: ${ }^{*} P<0.05$.

${ }^{\mathrm{a}}$ Dose in $\mathrm{mg} / \mathrm{kg}: 7,14$ and 28 , respectively. 
Table 3

Effect on uptake of $\mathrm{T}^{4} 4$ in total brain and brain structures in rats dosed with HCB

\begin{tabular}{lllll}
\hline Dose $(\mathrm{mmol} / \mathrm{kg})^{\mathrm{b}}$ & $\begin{array}{l}\text { Total brain } \\
(\mathrm{dpm} / \mathrm{mg})\end{array}$ & $\mathrm{OC}$ & $\mathrm{HP}$ & $\mathrm{TH}$ \\
\cline { 3 - 4 } & & & & \\
\hline 0.0 & $9.90 \pm 0.08$ & $50.0 \pm 6.3$ & $57.7 \pm 19.7$ & $67.7 \pm 20.4$ \\
2.6 & $5.35 \pm 1.28^{*}$ & $\mathrm{ND}$ & $\mathrm{ND}$ & $\mathrm{ND}$ \\
3.5 & $4.46 \pm 1.87^{*}$ & $22.2 \pm 5.5^{*}$ & $30.6 \pm 6.9^{*}$ & $39.2 \pm 17.3^{*}$ \\
\hline
\end{tabular}

Groups of rats $(n=3-5$ ) were repeatedly dosed with different doses of HCB for a period of 2 weeks (for total brain) or 4 weeks (brain structures). Following the last dose, $\left[{ }^{125}\right.$ IJT 4 was administered, and brains were removed and dissected, or not (see Methods for details). Differences in basal radiolabel levels in total brain and brain structures of control animals are due to different amounts of total label used in the two separate experiments. Results are expressed as mean values \pm S.D. Statistical significance: ${ }^{*} P<0.05$. ${ }^{a} \mathrm{OC}$, occipital cortex; HP, hippocampus; TH, thalamus.

${ }^{\mathrm{b}}$ Dose in $\mathrm{mg} / \mathrm{kg}$ : 750 and 1000, respectively. ND, not determined.

dependent accumulation of HCB as well as of PCP. PCP levels in serum were on the average $11 \%$ of the serum $\mathrm{HCB}$ concentrations after a 2-week exposure period and increased to $22 \%$ if the exposure period was prolonged to 4 weeks. The HCB concentration in brain tissue (Table 4) was about $16 \%$ of the HCB levels in serum after exposure to $3.5 \mathrm{mmol} \mathrm{HCB} / \mathrm{kg}$ for a period of 4 weeks.

It was then investigated whether the blood-CSF barrier would pose a strict limitation for entry of PCP into CSF. Different doses of PCP up to $64 \mu \mathrm{mol} / \mathrm{kg}$ (17 $\mathrm{mg} / \mathrm{kg}=1 / 3 \mathrm{LD}_{50}$ ) were given as a single dose to rats and PCP levels were deter-

Table 4

$\mathrm{HCB}$ and PCP concentrations in brain, CSF and serum of rats exposed to $\mathrm{HCB}$

\begin{tabular}{|c|c|c|c|c|c|c|}
\hline \multirow{2}{*}{$\begin{array}{l}\text { Dose } \\
(\mathrm{mmol} \\
\mathrm{HCB} / \mathrm{kg})^{\mathrm{a}}\end{array}$} & \multicolumn{2}{|l|}{$\mathrm{CSF}$} & \multicolumn{2}{|l|}{ Brain } & \multicolumn{2}{|l|}{ Serum } \\
\hline & $\mathrm{HCB}^{\mathrm{b}}$ & $\mathrm{PCP}^{b}$ & $\mathrm{HCB}^{\mathrm{C}}$ & $\mathrm{PCP}^{\mathrm{c}}$ & $\mathrm{HCB}^{\mathrm{h}}$ & $\mathrm{PCP}^{\mathrm{b}}$ \\
\hline 1.7 & $<0.2$ & $<0.1$ & ND & ND & $15.5 \pm 2.8$ & $1.8 \pm 0.57$ \\
\hline 2.6 & $<0.1$ & $<0.1$ & ND & ND & $23.6 \pm 4.0$ & $2.7 \pm 0.45$ \\
\hline 3.5 & $<0.1$ & $<0.1$ & ND & ND & $23.2 \pm 2.3$ & $2.6 \pm 0.52$ \\
\hline $3.5^{*}$ & ND & ND & $6.0 \pm 1.1$ & $<0.05$ & $38.5 \pm 7.2$ & $8.5 \pm 3.57$ \\
\hline
\end{tabular}

Groups of rats $(n=3-5)$ were repeatedly treated with different doses of HCB for a period of 2 or $4\left({ }^{*}\right)$ weeks. HCB and PCP concentrations in CSF, brain and serum were determined by HPLC analysis as described in Materials and Methods. Levels in brain are expressed on the basis of wet weight. Results represent mean values \pm S.D.

${ }^{a}$ Dose in $\mathrm{mg} / \mathrm{kg}$ : 500, 750 and 1000 , respectively.

${ }^{b}$ Concentration in $\mu \mathrm{mol} / 1$.

${ }^{\mathrm{c}}$ Concentration in $\mathrm{nmol} / \mathrm{g}$. ND, Not determined. 


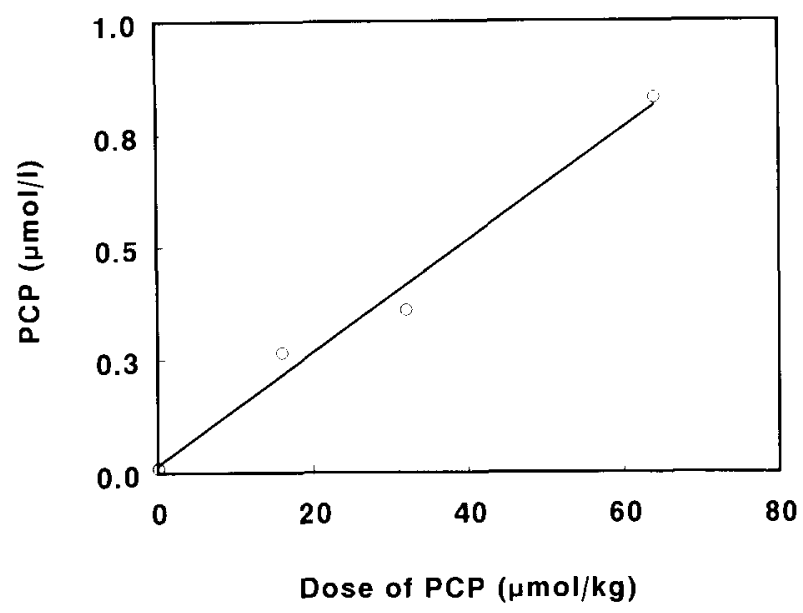

Fig. 2. Dose-dependent uptake of PCP in CSF. Different doses of PCP were i.v. administered to rats $(n=3-4)$. After $6 \mathrm{~h}, \mathrm{CSF}$ was collected and PCP levels were determined by HPLC. Results are expressed as the mean values.

mined in CSF by HPLC. The results, shown in Fig. 2, demonstrate that uptake of PCP into CSF was linearly related to the administered dose.

The time course of PCP uptake into CSF (Fig. 3), following a single dose of 64 $\mu \mathrm{mol} / \mathrm{kg}$, indicates a gradual increase to a steady state level that was achieved after about $6 \mathrm{~h}$. Thereafter, PCP levels in CSF declined and, after $24 \mathrm{~h}$, were essentially below the detection limit.

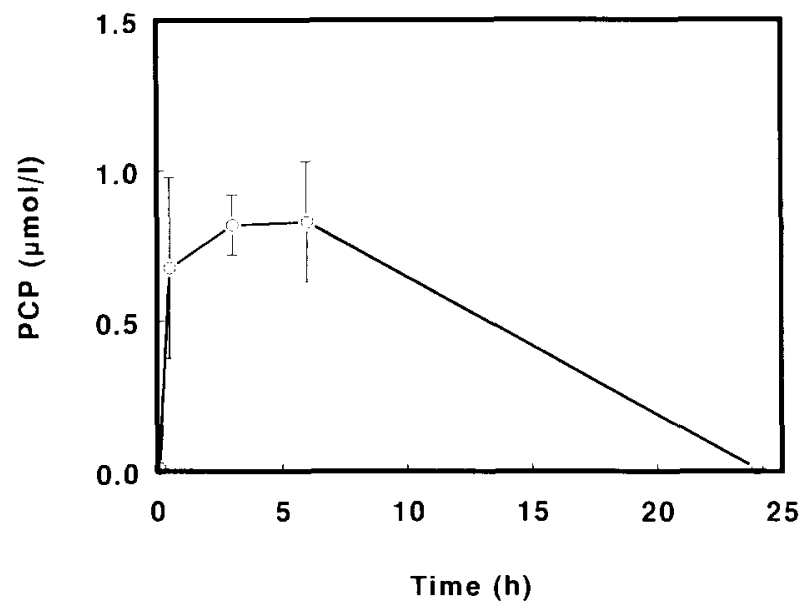

Fig. 3. Uptake of PCP in CSF. Rats $(n=3-4)$ received a single dose of $0.064 \mathrm{mmol}(17 \mathrm{mg}) \mathrm{PCP} / \mathrm{kg} \mathrm{At}$ several times after administration. CSF was collected and PCP concentration in CSF was analysed by HPLC. At $24 \mathrm{~h}, \mathrm{PCP}$ concentration in CSF was $<0.2 \mu \mathrm{mol} / \mathrm{l}$. Results are expressed as mean \pm S.E.M. 


\section{Discussion}

A vast amount of data is available now to indicate reductions of thyroid hormone levels, and more specifically T4, in experimental studies following exposure to halogenated aromatic compounds such as HCB (Rozman et al, 1986; Kleinman de Pisarev et al., 1989; Den Besten, 1992; Van Raaij et al, 1993b). One of the consequences of decreased plasma-levels of thyroxine may be that in certain target tissues levels of the biological active 3,5,3'-tri-iodothyronine (T3) are not adequately met. This may in particular hold for the brain as a target organ since more than $90 \%$ of the $\mathrm{T} 3$ content of the brain is derived from intracerebral conversion of T4 to T3 by deiodinating enzymes, rather than from plasma T3 (Silva and Matthews, 1984; Leonard and Visser, 1986). In view of this, levels of T3 in the brain are dependent on the supply of T4 from the circulation as well as upon activity of type II thyroxine 5 '-deiodinase.

Entry of T4 into the brain is via two major routes, the blood-cerebrospinal fluid (CSF) barrier formed by the choroid plexus (CP) and the blood-brain barrier (BBB) by the endothelium of cerebral capillaries (Johanson, 1989). The results from the present study indicate that exposure of rats to a polyhalogenated aromatic compound such as $\mathrm{HCB}$ has implications for a proper supply of $\mathrm{T} 4$ to the brain.

With respect to the blood-CSF barrier it was found that a repeated exposure regimen of rats to HCB did result in a strongly impaired uptake of peripherally administered T4 into CSF (by 37\%). Previously it has been shown that pentachlorophenol (PCP), the major metabolite of HCB, was more effective in altering plasma levels of T4 than the parent compound (Van Raaij et al, 1991a). The present results indicate that the same principle may apply for brain uptake of T4 since single doses of PCP did cause a large reduction of T4 uptake into CSF (up to 75\%). The mechanism(s) by which HCB and PCP inhibit brain uptake of T4 into CSF is not clear at present. It has been suggested that a separate pool of transthyretin (TTR), synthesized in the CP, is involved in transport of T4 to CSF (Schreiber et al., 1990). Since PCP is known to interact with the T4 binding site of TTR, it could compete with $\mathrm{T} 4$ for uptake into $\mathrm{CSF}$. Furthermore, the present results indicate that PCP may enter CSF (Figs. 2 and 3), possibly facilitated by the same mechanism. By occupying TTR binding sites for T4 in CSF, PCP could further impair intracerebral distribution of T4. Using different compounds with binding ability to TTR, for example a synthetic flavenoid (EMD 21388), arguments for such a mechanism have been obtained (Chanoine et al., 1992). Further studies with PCP are in progress to address this aspect more specifically. It cannot be excluded at this stage, however, that impaired cerebral uptake of T4 by $\mathrm{HCB}$ and PCP reflects to some extent the decreased plasma thyroxine levels.

For the capillary BBB, the second major route, carrier-mediated systems for thyroid hormone have been described (Pardridge, 1979). The present findings indicate a strongly decreased uptake of T4 by HCB in total brain tissue as well as in a few selected brain regions (by $42-56 \%$ ). This could be interpreted as direct interference of HCB or PCP with T4 transport systems in the BBB. The experimental set-up in the present study does, however, not allow a clear distinction to be made between 
T4 uptake through the $\mathrm{CP}$ or the $\mathrm{BBB}$. The reason for this is the free interchange of substances in CSF through the permeable ependymal lining of the ventricle into brain tissue and vice versa (Johanson, 1989). Therefore, the reduced uptake in total brain and brain structures could, partly or totally, reflect the reduced uptake in CSF. Experiments are in progress to determine the influence of these compounds only on T4 uptake through the BBB for which specific procedures exist (Oldendorf, 1970).

A reduced availability of thyroid hormones in the brain may have consequences for the normal functioning of neurochemical and neurophysiological processes. In particular the period of growth and development of the nervous system, in the perinatal phase, is critically dependent on adequate levels of thyroid hormone (Hadley, 1992). Whether during pregnancy the intracellular availability of T4 and T3 of the fetal brain may be impaired by compounds such as $\mathrm{HCB}$ or PCP, depends possibly on the period of maternal exposure and maternal thyroid function and TSH response on the one hand, and the fetal adaptive response in deiodinating capacity for local production of T3 from T4 on the other (Morreale de Escobar et al., 1988). Recent studies with perinatal exposure of rats to PCBs have indicated decreased fetal and neonatal plasma levels of T4 in association with increased type II thyroxine $5^{\prime}$ deiodinase activity in brain tissue (Morse et al., 1993). Accidental exposure of children to HCB, in the Turkey incident (Peters et al., 1982), has led to a number of persistent abnormalities concerning the thyroid, nervous system and stature. These symptoms are consistent with those of thyroid hormone deficiency during development, but this hypothesis remains to be proven. In adult subjects hypothyroidism may affect brain function to cause behavioral symptoms such as depression, paranoia and sleepiness. In adult animals morphological changes by hypothyroidism have been observed in the hippocampus (Gould et al., 1990), a neural area associated with cognitive processes. In view of the above mentioned general symptoms during hypothyroidism, it is possible that a reduced $\mathrm{T} 4$ supply to the adult brain might enhance the neurotoxicity of HCB or PCP.

In conclusion, the reduction of serum $\mathrm{T} 4$ levels by repeated administration of HCB or a single dose of the metabolite PCP appeared to directly affect the brain supply of T4. This may have consequences for proper brain development in exposed juveniles and neurological functions in exposed adults. Additional studies are required to more precisely determine the mechanism of T4 and PCP transport into CSF and brain tissue, including a possible role of TTR, and interference of PCP $(\mathrm{HCB})$ in this process.

\section{Acknowledgements}

This study was supported by the Netherlands Organization for Scientific Research (NWO) and the Directorate-General of Labour, Ministry of Social Affairs and Employment.

\section{References}

Ahlborg, U.G. and Thunberg. T.M. (1980) Chlorinated phenols: occurrence, toxicity, metabolism, and environmental impact. Critic. Rev. Toxicol. 7, 1. 
Aleshire, S.L., Bradley, C.A., Richardson, L.D. and Parl, F.F. (1983) Localization of human prealbumin in choroid plexus. J. Histochem. Cytochem. 31, 608.

Barter, R. and Claassen, C.D. (1992) UDP-glucurunosyltransferase inducers. reduce thyroid hormone levels in rats by an extrathyroidal mechanism. Toxicol. Appl. Pharmacol. 113, 36.

Bastomsky, C.H. (1974) Effects of a polychlorinated mixture (aroclor 1254) and DDT on biliary T4 excretion in rats. Endocrinology. 95, 1150.

Bastomsky, C.H., Murthy, P.V.N. and Banovac, K. (1976) Alterations in T4 metabolism produced by cutaneous application of microscope immersion oil: effects due to polychlorinated biphenyls. Endocrinology 98, 1309.

Beetstra, J.B., Van Engelen, J.G.M., Karels, P., Van der Hoek, H.J., De Jong, M., Docter, R., Krenning, E.P., Hennemann, G., Brouwer, A. and Visser, T.J. (1991) Thyroxine and 3,3',5-tri-iodothyronine are glucuronidated in rat liver by different uridine diphosphate-glucuronyltransferases. Endocrinology 128 , 741.

Brouwer, A. (1991) Role of biotransformation in PCB-induced alterations in vitamin A and thyroid hormone metabolism in laboratory and wildlife species. Biochem. Soc. Trans. 19, 731.

Brouwer, A. and Van den Berg, K.J. (1986) Binding of a metabolite of 3,4,3',4'-tetrachlorobiphenyl to transthyretin reduces serum vitamin $A$ transport by inhibiting the formation of the protein complex carrying both retinol and thyroxine. Toxicol. Appl. Pharmacol. 85, 301.

Byrne, J.J., Carbone, J.P. and Hanson, E.A. (1987) Hypothyroidism and abnormalities in the kinetics of thyroid hormone metabolism in rats trcated chronically with polychlorinated biphenyl and polybrominated biphenyl. Endocrinology 121, 520.

Chanoine, J.P., Alex, S., Fang, S.L., Stone, S., Leonard, J.L.. Körhle. J. and Braverman, L.E. (1992) Role of transthyretin in the transport of thyroxine from the blood to the choroid plexus, the cerebrospinal fluid and the brain. Endocrinology 130, 933.

Collins, W.T., Capen, C.C., Kasza, L., Carter, C. and Daily, R.E. (1977) Effect of polychlorinated biphenyl (PCB) on the thyroid gland of rats. Am. J. Pathol. 89, 119.

Curran, P.G. and DeGroot, L.J. (1991) The effect of hepatic enzyme-inducing drugs on thyroid hormones and the thyroid gland. Endocrine Rev. 12, 135.

Davies, P.H. and Franklyn, J.A. (1991) The effects of drugs on tests of thyroid function. Eur. J. Clin. Pharmacol. 40, 439.

Den Besten, C. (1992) The relationship between biotransformation and toxicity of halogenated benzenes: nature of the reactive metabolites and implications for toxicity. Thesis, Wageningen, The Netherlands.

Den Besten, C., Vet, J.J.R.M., Besselink, H.T., Kiel, G.S., Van Berkel, B.J.M., Meems, R. and Van Bladeren, P.J. (1991) The liver, kidney and thyroid toxicity of chlorinated benzenes. Toxicol. Appl. Pharmacol. 111, 69.

Dickson, P.W., Aldred, A.R., Marley, P.D., Guo-Fen, T., Howlett, G.J. and Schreiber, G.J. (1985a) High prealbumin and transferrin mRNA levels in the choroid plexus of rat brain. Biochem. Biophys. Res. Commun. 127, 890 .

Dickson, P.W., Howlett, G.J. and Schreiber, G. (1985b) Rat transthyretin (prealbumin): molecular cloning, nucleotide sequence, and gene expression in liver and brain. J. Biol. Chem. 260, 8214 .

Dickson, P.W. and Schreiber, G. (1986a) High levels of mRNA fot transthyretin (prealbumin) in human choroid plexus. Neurosci. Lett. 66, 311

Dickson, P.W., Aldred, A.R., Marley, P.D., Bannister, D. and Schreiber, G. (1986b) Rat choroid plexus specializes in the synthesis and the secretion of transthyretin (prealbumin). Regulation of transthyretin synthesis in choroid plexus is independent from that in liver. J. Biol. Chem. 261. 3475.

Dickson, P.W., Aldred, A.R., Menting, J.G.T., Marley, P.D., Sawyer, W.H. and Schreiber, G. (1987) Thyroxine transport in choroid plexus. J. Biol. Chem. 262. 13907.

Goldey, E.S. and Taylor, D.H. (1992) Developmental neurotoxicity following premating maternal exposure to hexachlorobenzene in rats. Neurotoxicol. Teratol. 14, 15.

Gould, E., Allan, M.D. and McEwen (1990) Dendritic spine density of adult hippocampal cells is sensitive to thyroid hormone. Brain Res. 525, 327.

Gray, L.E., Ostby, J., Marshall, R. and Andrews, J. (1993) Reproductive and thyroid effects of low-level polychlorinated biphenyl (Aroclor 1254) exposure. Fund. Appl. Toxicol. 20, 288. 
Hadley, M.E. (1992) Thyroid hormones. In: Endocrinology, 3rd Edn., Prentice Hall, International Editions.

Herbert, J., Wilcox, J., Pham, K.T., Fremeau, R.T., Zeviani, M., Dwork, A., Soprano, D.R., Makover, A., Goodman, D.S., Zimmerman, E.A., Roberts, J.L. and Schon, E.A. (1986) Transthyretin: a choroid specific transport protein in human brain. Neurology 36, 900.

Johanson, C.E. (1989) Potential for Pharmacologic Manipulation of the Blood-Cerebrospinal Fluid Barrier. In: E.A. Neuwelt (Ed), Implications of the Blood-Brain Barrier and Its Manipulation. 1. Basic Science Aspects, edited by New York: Plenum Publishing Corporation, p. 223.

Kato, M., Soprano, D.R., Makover, A., Kato, K., Herbert, J., Goodman, D.S. (1986) Localization of immunoreactive transthyretin (prealbumin) and of transthyretin mRNA in fetal and adult rat brain. Differentiation. 31, 228.

Kleinman de Pisarev, D.L., Sancovich, H.A. and Ferramola de Sancovich, A.M. (1989) Enhanced thyroxine metabolism in hexachlorobenzene intoxicated rats. J. Endocrinol. Invest. 12, 767.

Kleiman de Pisarev, D.L., Carmen Rios de Molina, M. and San Martin de Vale, L.C. (1990) Thyroid function and thyroxine metabolism in hexachlorobenzene induced porphyria. Biochem. Pharmacol. 39 , 817.

Koss, G., Koransky, W. and Steinbach, K. (1976) Studies on the toxicology of hexachlorobenzene. II. Identification and determination of metabolites. Arch. Toxicol. 35, 107.

Leonard, J.L. and Visser, T.J. (1986). In: G. Hennemann (Ed), Thyroid Hormone Metabolism, M. Dekker, New York, p. 189.

Morreale de Escobar, G., Obregon, M.J. and Escobar del Rey, F. (1988) Maternal-fetal thyroid hormone relationships and the fetal brain. Acta Med. Austriaca 15, 66.

Morse, D.C., Groen, D., Veerman, M., Van Amerongen, C.J., Koeter, H.B.W., Smits Van Prooije, A.E., Visser, T.J., Koeman, J.H. and Brouwer, A. (1993) Interference of polychlorinated biphenyls in hepatic and brain thyroid hormone metabolism in fetal and neonatal rats. Toxicol. Appl. Pharmacol. 122, 27.

Nilsson, C., Lindvall-Axelsson, M. and Owman, C. (1992) Neuroendocrine regulatory mechanisms in the choroid plexus-cerebrospinal fluid system. Brain Res. Rev. 17, 109.

Oldendorf, W.H. (1970) Measurement of brain uptake of radiolabeled substances using a tritiated water internal standard. Brain Res. 24, 372.

Pardridge, W.M. (1979) Carrier-mediated transport of thyroid hormones through the rat blood-brain barrier: primary role of albumin-bound hormone. Endocrinology 105, 605 .

Peters, H.A., Gockmen, A., Cripps, D.J., Bryan, G.T. and Dogramaci, I. (1982) Epidemiology of hexachlorobenzene-induced porphyria in Turkey. Arch. Neurol. 39, 744.

Preston, J.E. and Segal, M.B. (1992) Saturable uptake of $\left[{ }^{125}\right.$ I]l-tri-iodothyronine at the basolateral (blood) and apical (cerebrospinal fluid) sides of the isolated perfused sheep choroid plexus. Brain Res. $592,84$.

Rogan, W.J. and Gladen, B.C. (1992) Neurotoxicology of PCBs and related compounds. In: A. Mutti, L.G. Costa, J.M. Manzo and J.M. Cranmer (Eds), Current Issues in Neurotoxicology, Little Rock: Intox Press, Inc., p. 27.

Rogan, W.J., Gladen, B.C., McKinney, J.D., Carreras, N., Hardy, P., Thullen, J., Tinglestad, J. and Tully, M. (1986) Neonatal effects of transplacental exposure to PCBs and DDE. J. Pediatr. 109, 335.

Rozman, K., Gorski, J.R.. Rozman, P. and Parkinson, A. (1986) Reduced serum thyroid hormone levels in hexachlorobenzene induced porphyria. Toxicol. Lett. 30. 71.

Schreiber, G., Aldred, A.R., Jaworoski, A., Nilsson, C., Achen, M.G. and Segal, M.B. (1990) Thyroxine transport from blood to brain via transthyretin synthesis in choroid plexus. Am. J. Physiol. 27, R338.

Silva, J.E. and Matthews, P.S. (1984) Production rates and turnover of tri-iodothyronine in ratdeveloping cerebral cortex and cerebellum. J. Clin. Invest. 74, 1035.

Soprano, D.R., Herbert, J., Soprano, K.J. and Schon, E.A. (1986) Transthyretin: a choroid specific transport protein in human brain. Neurology $36,900$.

Tilson, H.A., Jacobson, J.L. and Rogan, W.J. (1990) Polychlorinated biphenyls and the developing nervous system: cross-species comparisons. Neurotoxicol. Teratol. 12, 239

Van den Berg, K.J. (1990) Interaction of chlorinated phenols with thyroxine binding sites of human transthyretin, albumin and thyroid binding globulin. Chem. Biol. Interact. 76, 63. 
Van den Berg, K.J., Zurcher, C. and Brouwer, A. (1988) Effects of 3,4,3',4'-tetra chlorobiphenyl on thyroid function and histology in marmoset monkeys. Toxicol. Lett. 41, 77.

Van den Berg, K.J., Van Raaij, J.A.G.M., Bragt, P.C. and Notten, W.R.F. (1991) Interactions of halogenated industrial chemicals with transthyretin and effects on thyroid hormone levels in vivo. Arch. Toxicol. 65, 15.

Van Ommen, B., Van Bladeren, P.J., Temmink, J.H.M. and Muller, F. (1985) Formation of pentachlorophenol as the major product of microsomal oxidation of hexachlorobenzene. Biochem. Biophys. Res. Commun. 126, 25.

Van Ommen, B., Adang, A.E.P., Brader, L., Posthumus, M.A., Muller, F. and Van Bladeren, P.J. (1986) The microsomal metabolism of hexachlorobenzene. Origin of the covalent binding to protein. Biochem. Pharmacol. 35, 3233.

Van Raaij, J.A.G.M., Van den Berg, K.J., Bragt, P.C., Engel, R. and Notten, W.R.F. (1991a) Effects of hexachlorobenzene and its metabolites pentachlorophenol and tetrachlorohydroquinone on serum thyroid hormone levels in rats. Toxicology 67, 107.

Van Raaij, J.A.G.M., Van den Berg, K.J. and Notten, W.R.F. (1991b) Hexachlorobenzene and its metabolites pentachlorophenol and tetra-chlorohydroquinone: interaction with thyroxine binding sites of rat thyroid hormone carriers ex vivo and in vitro. Toxicol. Lett. 59, 101.

Van Raaij, J.A.G.M., Kaptein, E., Visser, T.J. and Van den Berg, K.J. (1993a) Increased glucuronidation of thyroid hormone in hexachlorobenzene treated rats. Biochem. Pharmacol. 45, 627.

Van Raaij, J.A.G.M., Frijters, C.M.G. and Van den Berg, K.J. (1993b) Hexachlorobenzene induced hypothyroidism: Involvement of different mechanisms by parent compound and metabolite. Biochem. Pharmacol. 46, 1385.

Visser, T.J., Kaptein, E., Van Raaij, J.A.G.M., Tjong Tjin Joe, C., Ebner, T. and Burchell, B. (1993a) Multiple UDP-glucuronyltransferases for the glucuronidation of thyroid hormone with preference for 3,3',5'-tri-iodothyronine (reverse T3). FEBS. Lett. 315, 65.

Visser, T.J., Kaptein, E., Van Toor, H., Van Raaij, J.A.G.M., Van den Berg, K.J., Tjon Tjin Joe, C., Van Engelen, J.G.M. and Brouwer, A. (1993b) Glucuronidation of thyroid hormone in rat liver: Effects of in vivo treatment with microsomal enzyme inducers and in vitro assay conditions. Endocrinology 133, 2177. 